DOI: 10.14807/ijmp.v11i9.1429

\title{
LIMITATIONS OF THE CONCEPT OF PERMANENT ESTABLISHMENT AND E-COMMERCE
}

\author{
Marius Laurinaitis \\ Mykolas Romeris University, Lithuania \\ E-mail:marius@laurinaitis.eu
}

Darius Stitilis

Mykolas Romeris University, Lithuania

E-mail: stitilis@mruni.eu

Irmantas Rotomskis

Mykolas Romeris University, Lithuania

E-mail:marius@laurinaitis.eu

Otabeg Azizov

Kharkiv Petro Vasylenko National Technical University of Agriculture, Ukraine E-mail:tmcool777@gmail.com

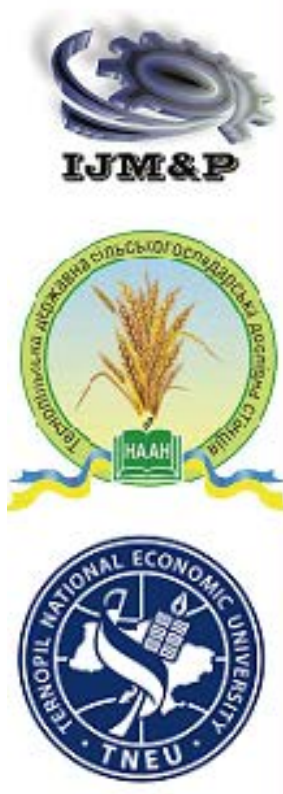

Nataliia Marchuk State Agrarian and Engineering University in Podilya, Ukraine E-mail:nata.marchuk2205@gmail.com

Submission: 8/20/2020

Revision: 9/03/2020

Accept: 9/04/2020

\section{ABSTRACT}

The concept of permanent establishment introduced over a century ago became obsolete in the XXI age. It is completely irrelevant in terms of modern online business. Recent OECD initiatives are only a late reaction to the internationally observed legal loophole in taxing profits of e-commerce companies. Steps taken by the international community over the last few years reveal considerable diversity in approaches towards the concept of permanent establishment. Even the key principles to be followed in the development of the new concept of permanent establishment have not been agreed so far. The present article is an attempt to propose the major principles to be followed in updated interpretations of the concept of permanent establishment equally effective in terms of both big multinationals and SMEs.

Keywords: Permanent establishment; E-commerce taxation; Digital economy taxation 
ISSN: 2236-269X

DOI: 10.14807/ijmp.v11i9.1429

\section{INTRODUCTION}

European governments emphasize the need of a fair and effective taxing system in the digital era (EUROPEAN COMMISSION, 2017) ${ }^{1}$. The major problem, however, is how to successfully combine efficiency of the newly developed system with fair taxation. Fair taxation is actually about how to fairly confer the right to levy profit taxes imposed in international trade on a nation state (HONGLER; PISTONE, 2015). The existing taxation systems adopted by contemporary nation states may be subdivided into two types: source states and resident states (FAULHABER, 2019).

The balance between the source state and the resident state has been of key importance in dealing with double taxation issues for over 100 years. To deal with the problem, the concept of permanent establishment was introduced as a key legal instrument regulating cross-border relations Introduction of the permanent establishment allowed successful combination of residence state taxation, applicable in domestic trade, with source state taxation, widely adopted in international trade.

In the XX century, operation of an offshore business in its full capacity was hardly possible without a locally established representative subject (DANON; SPINOSA; TURINA, 2018). Businesses adopted a more or less uniform understanding of the requirements for business representation to be relevant and sufficient to open a permanent establishment in the target state independently on the fact of rendering certain services in its territory ${ }^{2}$. The understanding was greatly contributed by OECD interpretation of the PE concept and judicial

1 „Since the start of its mandate, this Commission has taken action to ensure the principle that all businesses operating in the EU should pay their taxes where profits and value are generated. This principle is essential for a fair and effective taxation in the Single Market, and it can only be enforced through common and coordinated measures“.

${ }^{2}$ A radio broadcasting company set up in Mexico broadcasted their programs to the USA. The company charged the US listener a fee collected directly from the customer and only used mail boxes located in the US. The court held that mail delivery was not of the same importance as company's headquarters or commercial operations in the USA. The company's premises and facilities were located in the Mexican territory. Advertising contracts were also drawn up in Mexico. All business operations necessary to render the service took place in the company's studio in Mexico. Finally, the court ruled that the source of income was not in the US territory since all operations to render the service (i.e., radio broadcasting) were conducted in Mexico. The court, however, had no doubts that the audience was in the US territory and the advertising was targeted specifically at the US listener. The case is more than 70 years old and similar situations have to be treated today in view of opportunities granted by the Internet. (Piedras Negras Broadcasting Co. v. Commissioner, 43 B.T.A. 297 (1941), nonacq., 1941-1 C.B. 18, aff'd, 127 F.2d 260 (5th Cir. 1942)) 
DOI: 10.14807/ijmp.v11i9.1429

practice extending the PE perception without prejudice to the key principle, that is the state's right to collect profit tax where the latter is gained from its citizens and the company has a permanent establishment in the form of a material object.

However, the situation has changed with the arrival of the digital era. E - commerce companies have become so flexible that they are able to conduct their business in several counties simultaneously by introducing new business models to enjoy tax deductions offered by the legislator ${ }^{3}$. However, the most important thing is that the companies can successfully operate having no object to represent their permanent establishment in the countries (DANON; SPINOSA; TURINA, 2018).

It has become very difficult or, in the case of small and medium business, impossible for the state to identify the actual location of the source of the corporate revenue. Corporate income is distributed so as to leave the state no opportunity to impose taxes on the income ("stateless income") (TURINA, 2019). Also, international companies working in the digital economy (typically set up in economically developed countries) may operate in their full capacity in the market of developing countries without physical presence in their territory escaping the burden of tax in the country of operation (HONGLER; PISTONE, 2015).

The major objects debated in the end of the XX century and the beginning of the XXI century as potentially suitable to represent company's permanent establishment were the server and the website of the company.

\section{METHODOLOGY}

Methodologically, this research focuses on the global regulation of electronic commerce taxation in comparison with the regulation initiatives in separate regional (such as EU) or individual countries, and also on the understanding of fair and efficient international taxation in the legal doctrine. The authors use qualitative research methods, such as the method of textual analysis and the analysis of case law in the field of electronic commerce taxation.

\section{LITERATURE REVIEW}

\subsection{Historical review: the server, the website and the permanent establishment}

A company's server used to be considered the most popular instrument to substitute the permanent establishment of an e-commerce company operating in a foreign market. Already

${ }^{3}$ Double Irish Dutch Sandwich technique used by Google may be a good example of a business structure designed to avoid income taxing. 
DOI: 10.14807/ijmp.v11i9.1429

in 2000, the approach was reflected in commentaries on Article 5 of OECD Model Tax Convention. The commentaries extended treatment of the permanent establishment in view of e-commerce realis, which remained unchanged until 2017, when OECD updated Model Tax Convention.

Assessment of the server's suitability as a company's permanent establishment in a foreign market has to be grounded on standard criteria set for a permanent establishment:

- business operations must not be limited to preparatory and ancillary works,

- the server has to be constantly used for business operations,

- its location has to be permanently fixed.

Operations of a foreign company cannot be considered business operations and the company cannot be considered having a permanent establishment if its e-commerce operations are limited to ancillary works foreseen in Article 5 paragraph 4 of the OECD Model Tax Convention. Already in 1998, the Ottawa conference (TAXATION AND ELECTRONIC COMMERCE, OECD 2001) accentuated e-commerce activities that may be ascribed to ancillary and preparatory works according to Article 5 paragraph 4 of the OECD Model Tax Convention (the activities, as a matter of fact, cannot make an essential and significant part of the activity of the enterprise as a whole):

- providing a communication link - much like a telephone line - between suppliers and customers;

- advertising of goods and services;

- relaying information through a mirror server for security and efficiency purposes;

- gathering market data for enterprise;

- supplying information (MODEL TAX CONVENTION, 2017).

Here, supply of information is understood not as provision of goods or services to the end user, but as an interim act in negotiating a deal where rendering information to a contractor or a third party is necessary.

The convention also pointed out key activities of e-commerce (eventually transposed to the commentary on OECD Model Tax Convention) that may allow recognition of specific activities as business activities in the target country:

- entering into a business transaction with a client,

- payment for acquired goods or services,

- automatic delivery of goods by means of facilities in the target country. 
DOI: 10.14807/ijmp.v11i9.1429

However, there is one essential thing that may help distinguish between the core and ancillary business activities. According to OECD, the activities are attributable to the existence of the server and their accomplishment is inseparable from the server's functional capabilities. The server is definitely a part that is necessary to accomplish the activities. However, the key item to trigger the activities and ensure smooth performance and control is the company's website.

The fact that the activities are automated is essentially predetermined by the used software. Meanwhile, the company's website may be treated as a combination of software and electronic data. Also. the scope of functions chosen by the end user depends on opportunities offered by the website. In case of two identical servers, possibilities to perform certain activities may be completely different as the possibilities directly depend on the websites hosted on the servers.

Probably, less discussions in the context of e-commerce arise about business continuity. The OECD recommended 12-month period (often limited to 6 months in practice) is usually agreed in traditional business as well in view of specific circumstances ${ }^{4}$. In that sense, ecommerce implies no additional circumstances that may not be agreed upon by international agreements.

Probably most attention should be paid to the fixed place of business requirement. Before emergence of e-commerce, understanding of the place of business was essentially based on the territorial principle. OECD Model Tax Convention gives no exact definition of the place of business. The definition is also absent in international treaties for avoidance of double taxation.

However, Article 5 paragraph 1 of the OECD Model Tax Convention and Commentaries on the Convention allow identification of certain elements helping understand the concept of the place of business: "certain amount of space at enterprise disposal which is

\footnotetext{
${ }^{4}$ Some jurisdictions acknowledge that a circus has to have its permanent establishment even if it constantly moves from one location to another. Other countries, however, refuse to acknowledge existence of its permanent establishment as circle performances are given in changing locations (SKAAR, 2000). When business activities are inseparable from a specific geographical location, a period of several weeks may be applied. However, the Norwegian Supreme Court denied a permanent establishment in Alphawell case for a consultancy firm which used a number of different offices for 6 months in certain intervals within a period of 4 years. The court held that the degree of business continuity was insufficient. (Alphawell Ltd and Richard Pegrum v Ministry of Finance, Høyesterett (Norwegian Supreme Court), 10 June 1994, Case number 56/994)
} 
DOI: 10.14807/ijmp.v11i9.1429

used for business activities"; "area in a customs depot"; "business facilities of another enterprise", etc.

There is no requirement for a specific location to run a business. Instead, relation to a certain territory is emphasized (important aspects include the time-period and performed functions). The formal requirement for enterprises to have legal grounds for business activities in particular premises is not necessary.

However, understanding of the place of business is impossible without linking it to an object having a physical expression. Securities, bank accounts, and intangibles cannot be places of business (SKAAR, 2000). OECD Model Tax Convention says nothing about airspace as a possible place of as in such case, according to GUTMAN (2001), we would have to talk not only about physically tangible subjects, but about the concepts of time and space as well.

Existence of the place of business is also subject to another criterion, namely, it must be "fixed", i.e. there must be a "link between the place of business and a specific geographical point". The narrow understanding of the place of business has led to the situation where, according to OECD interpretation, only a server may have a physical location and such location may thus constitute a "fixed place of business" of the enterprise that operates that server.

Big companies normally have their own servers whereas small and medium ecommerce businesses, which may have their websites hosted on extramural servers out of their direct control (quite a frequent situation in e-commerce), have been neglected by OECD. Whereas, according to OECD, a website hosted on a server is an intangible item, that it, has no physical expression in a particular place, it cannot be sufficient for the enterprise to be considered having a permanent establishment ${ }^{5}$.

Thus, an essential condition for a place of business to be specified is its geographical location within the boundaries of the country. No place of a foreign business outside the country's territory can create a permanent establishment within its jurisdiction. „It is difficult to apply the current system of giving the source country priority in taxing active income while the country of residence has priority in taxing passive income to e-commerce because the current system does not produce a result that accurately reflects the economic source of the income or the location of the economic activity“ (BASU, 2017).

${ }^{5}$ Conditions stipulated in the hosting contract have no importance in this case. Even if the hosting contract stipulates which particular server the company's website has to be hosted on, the hosting contract will not be treated as sufficient grounds for the company to have a permanent establishment. 
DOI: 10.14807/ijmp.v11i9.1429

The purpose of the study is to investigate which principles must be fundamental in addressing the development of an international taxation system for e-commerce. Adherence to these principles must be unconditional. We will see that the lack of common values does not allow for an effective fight against tax evasion. The principles of fairness and efficiency must underpin the formation of common values for all states.

\section{RESULTS AND DISCUSSION}

\subsection{Research of fair and efficient principles in e-commerce taxation}

Speaking of the OECD's interpretation of the permanent establishment in terms of ecommerce, it has to be noted that its approach has been quite successfully oriented towards implementation of an efficient taxation system. This is predetermined by linking a permanent establishment to a server as an object having a physical expression easy to fix and control. The solution also leaves no uncertainties of permanent establishment where the website is hosted on an extramural server.

However, apart from being efficient, the international taxing system has to be fair. The country where the host server is located may have nothing to do with business activities carried out by the enterprise. An attractive tax system may be the only reason for the enterprise to have its server in the country. It is particularly relevant to small and medium enterprises, which have no problem with mobility and are willing to save on taxes by exploiting loopholes in the tax system. One of the techniques used by huge multinationals is by opening their branches in various low tax jurisdictions. The problem may be well illustrated by French ${ }^{6}$ and Spanish $^{7}$ cases.

${ }^{6}$ Google France (Google subsidiary) was rendering marketing services and analysis of AdWords services rendered to the French customer by Google Ireland (Google subsidiary) under a cooperation contract. Google France had no right to contract with clients on behalf of Google Ireland. The French Tax Administration (FTA) argued that Google Ireland, having used Google France employees (Google France employees negotiated Google Ireland contracts with the customer, the contracts contained names of Google France employees, Google France hired legal advisers to negotiate the contracts), technologies and market data, de facto had a permanent establishment in France. The Paris Administrative Tribunal refused to acknowledge Google Ireland's permanent establishment within French jurisdiction as FTA was claiming. Google France activities were deemed axillary in view of the fact that it had no right to enter into contract with the customer and therefore Google Ireland's representation in France was insufficient. (Google Ireland Limited v. Administration générale des finances publiques, Case 1505113/1-1, Tribunal administratif de Paris (12 July 2017)).

${ }^{7}$ Dell Spain (Dell Inc. subsidiary) was an authorized Dell Inc. distributor. After restructuring, Dell Spain acted on the basis of a commissionaire agreement with Dell Ireland. The company's main activity was to 
DOI: $10.14807 /$ ijmp.v11i9.1429

The above-mentioned cases are good examples of how decisions based on a narrow understanding of permanent establishment result in unfair taxing of the income of foreign base companies. The two examples obviously show how the company's income gained from the French citizen falls outside the country's jurisdiction. Traditionally, for the sake of taxing, a commissionaire was not deemed a subordinate agent and its performance created no permanent establishment if the principal had no other representation in the target country. The approach has been followed by courts in the XXI century as well ${ }^{8}$. Meanwhile, a broader understanding of permanent establishment would allow the source state to enforce its right to collect taxes from income generated in its jurisdiction ${ }^{9}$.

Divergence in approaches may be observed not only on the international scale. Even within the same state, different institutions (typically tax authorities and courts) often have different approaches towards the grounds for a permanent establishment to arise ${ }^{10}$.

The Spanish court decision allows an assumption that the key provisions of the source state taxation are no longer compatible with the narrow understanding of the permanent establishment.

The source state has to preserve its right to impose tax on income gained from its citizens by a foreign enterprise. OECD approach on how to attribute profits to permanent establishments of e-commerce companies, adopted 20 years ago, is based on a traditional requirement of a physical object absolutely irrelevant in the electronic environment ${ }^{11}$.

render services specially designed for large corporate clients. The Supreme Court held that such Dell Spain activities create Dell Ireland's permanent establishment according to provisions of the double taxation agreement on a subordinate agent and a fixed place of business. The court also stated that the requirement for a subordinate agent to be „acting on behalf of an enterprise“ implies no necessity to interpret it as direct representation whereas a permanent establishment associates not only with particular premises, but has to be interpreted wider to include actual links between the enterprise and the agent manifesting in daily activities of the latter in accordance with instructions and management of the enterprise. (Spain vs. Dell, June 2016, Supreme Court, Case No. 1475=2016)

${ }^{8}$ France vs. Zimmer Ltd., March 2010, Conseil D’Etat No. 304715, 308525; Norge vs. Dell Norge. December 2011, HRD saknr 2011-755.

${ }^{9}$ Spain vs. Dell, June 2016, Supreme Court, Case No. 1475/2016. See also: India vs Mastercard, June 2018, AAR No 1573 of 2014.

${ }^{10}$ This may be well illustrated by France vs Valueclick Ltd. March 2018, CAA, Case no 17PA01538

${ }^{11}$ The requirement, however, has never been absolute. A certain category of the corporate profit could always be taxed by the source state, in spite of the absence of the permanent establishment in the state. The right was enforced in Article 6 and 13 of the OECD Model Tax Convention. National courts have also been flexible about corporate possession of tangible assets in the target country. In Formula One World Championship 
DOI: $10.14807 /$ ijmp.v11i9.1429

The requirement is in line with classical judicial doctrines, but completely irrelevant in the modern digital era ${ }^{12}$. Although it was noted already on the issuance of the new commentary on OECD Model Tax Convention of 2000, wider debates on the mandatory physical company representation in the target country being incompatible with the modern digital economics started only very recently (ORGANISATION FOR ECONOMIC CO-OPERATION AND DEVELOPMENT, 2018).

Such understanding of the permanent establishment may lead towards tax competition between nation states, which has already been observed in the clash between national tax systems and e-commerce (REUVEN, 2000). Nation states have already taken measures to introduce digital service taxes aimed at modification of the outdated system of international taxation.

Sporadic measures by individual nation states may overlap with equivalent decisions of other nation states. As a result of such competition, businesses are likely to face hindrances negatively affecting development of e-commerce (ORGANISATION FOR ECONOMIC COOPERATION AND DEVELOPMENT, 2018). The ultimate objective should be an agreement on how to properly differentiate corporate income according to the income source and impose corresponding taxation norms.

Ltd. Vs. Commissioner of Income Tax case in 2017, the Supreme Court of India held that the Buddh International Circuit may be deemed a prmanent establishment for commercial/business activities in F1 Championship. The Supreme Court stated that: the race track was "a virtual projection of the foreign enterprise of one country into the soil of another country"; the enterprise was conducting business activities; the place of business was,, "fixed"; and the place of business was in the company's disposal. In Formula One World Championship Ltd. Vs. Commissioner of Income Tax, International Taxation - 3, Delhi \& Anr. 2017).

${ }^{12}$ It has to be noted though, that OECD is not the only to maintain this approach. In terms of indirect taxing, the European Union had been clinging to practices incompatible with the digital era for decades on the same grounds of the supremacy of physical objects. The EU scheme of taxation of electronic services introduced at the beginning of the century and later transformed into MOSS (Mini One Stop Shop) was aimed at the development of a uniform registration and VAT accounting scheme for non-European Union e-commerce companies operating within the EU jurisdiction. The initial VAT accounting initiatives were not allencompassing. Therefore, application of a reduced VAT rate to printed books and the standard rate to e-books had long remained a norm whereas the only criterion to differentiate the former from the latter was their tangibility. E-books were treated as services and therefore were subject to different legal norms than goods. When France and Luxembourg unilaterally decided to apply a reduced VAT rate to electronic books in 2012, the EU Commission banned the reduction on the grounds of violation of EU law. Only in 2018, the European Commission changed its decision and allowed a reduced VAT rate for electronic books. It took almost two decades though. 
DOI: $10.14807 /$ ijmp.v11i9.1429

Even the digital service taxes considered by nation states today are aimed at individual subjects, namely, at big multinationals. In France, digital service taxes are even referred to as GAFA $^{13}$ tax. Similar decisions, e.g. Diverted Profits Tax (DPT), have been debated in the UK as well ${ }^{14}$. Initiatives have been set up in Italy, Spain, Poland and Austria. As a rule, the new taxes aim at avoiding application of the norm of permanent establishment.

The new taxes are not normally coordinated with other countries and have already caused international disputes. Until measures taken by governments are exceptionally oriented to huge multinationals, the majority of small and medium e-commerce companies will remain beyond the boundaries of a fair and efficient taxing system. Therefore, it is crucial to address the issue of double taxation on a multilateral and not on a single state level.

Of course, the multilateral level cannot be understood as all-encompassing and universally recognized and applied. That would definitely be impossible ${ }^{15}$. However, in view of long-term ambitions to develop a sustainable taxation system, scholars refer to eliminating (where possible) the deep-rooted tax sovereignty as an option possible in combination with an ultimate authority (VAN RAAD, 2001).

The tax law is about to lose its efficiency with the emergence of e-business. The trend may be observed in other spheres as well. For instance, U.S. sales tax regulation in e-commerce has to subject to standard requirements set by the Congress since uncoordinated measures introduced by individual states are likely to create additional barriers to businesses undergoing different norms set by individual states at the same time (HMAYAKYAN, 2019). It seems that the holistic approach may be one of the most viable ways to develop an efficient taxation system in the digital economy.

It seems that the holistic approach may be one of the most viable ways to develop an efficient taxation system in the digital economy.

\subsection{Results: an alternative to the permanent establishment}

Following long discussions, the international community has finally made initial steps to shift from the physical nature of the permanent establishment. In 2018, OECD acknowledged

${ }^{13}$ GAFA is acronym for Google, Apple, Facebook and Amazon - the 4 most powerful e-commerce companies in the U.S.

${ }^{14}$ DPT is not applicable to small and medium enterprises.

15 „The grand illusion of a single, worldwide tax system that would eliminate all international inefficiencies and assist all the nations of the world in maximizing their relative advantages is commonly accepted as utopian.“ (BRAUNER, 2003). 
DOI: 10.14807/ijmp.v11i9.1429

that a PE threshold "generally has the effect of deeming a PE to exist in circumstances where one would not ordinarily exist under the traditional application of the PE definition" (ORGANISATION FOR ECONOMIC CO-OPERATION AND DEVELOPMENT, 2018).

The wider approach to the concept of permanent establishment allows extending its boundaries by refusing physical representation of businesses and a fairer distribution of the corporate taxation among individual nation states. For a company to be deemed having a permanent establishment, its "digital presence" or "service permanent establishment" are enough.

The new approach also allows enterprises not to worry about their representation in the target country and focus on their business efficiency. Universal acceptance of this approach would help achieve two important goals:

- nation states would be given an opportunity to impose taxes on profits generated within their territories by enterprises registered outside their boundaries making taxing dependent on the source and not on the place of registration and reducing hereby tax competition between individual countries;

- there would be no need for enterprises to move their business to favourable tax states including tax havens and jurisdictions with more favourable tax treatment.

However, it has to be noted that the new definition of a permanent establishment also entails certain risks to be taken into account. For example, it is very difficult to define strict boundaries of such permanent establishment. The complexity of the task and the requirement to legitimately attribute profit to the permanent establishment may cause loopholes leading to "full taxation of income attributable to the Virtual PE to no source taxation at all" (MORENO; BRAUNER, 2019).

The fact that a great deal of nation states have a positive approach to the new interpretation of permanent establishment proposed by OECD means the approach may someday become universal. Several nation states have already made first steps defining new treatment of permanent establishment and setting criteria for its existence.

Even before the recent discussions, Israel had treated the concept of permanent establishment wider than it is described in OECD Model Tax Convention. A permanent establishment is defined here as inseparable from income-producing activities of an enterprise. Therefore, it is not surprising that Israel was among the first to produce an official circular on Internet activity of foreign companies in Israel (the circular) in 2015-2016. Israeli Tax Authorities rely upon the concept of "significant economic presence", oriented towards 
DOI: 10.14807/ijmp.v11i9.1429

challenges of the digital economy. It has to be noted, though, that the concept is only applicable where countries have no double taxation agreement. Significant economic presence may be applied to enterprises that have no tangible assets in Israel, but are deemed to be having „digital presence". Possible applications may include:

- Online contract conclusion: a significant number of contracts are concluded online between the foreign company and Israel customers;

- Use of digital products and services: the foreign company offers online services/products that are used by a significant number of Israel customers;

- Localised web site: the foreign company employs a website with localised features targeted at the Israel market (e.g., Hebrew language, local discounts and marketing, local currency and payment options);

- Multi-sided business model: the company generates significant revenue that is closely related to the volume of online activities performed by users located in Israel (ORGANISATION FOR ECONOMIC CO-OPERATION AND DEVELOPMENT, 2018).

Similar provisions on corporate taxation were adopted in India in 2019. A company with no residence in India can still be deemed having "significant economic presence" and be subject to income taxation if:

- its annual revenue exceeds a set limit, independently on whether the revenue is gained from trading in goods, services or assets including data or software downloading,

- and it has a certain number of customers constantly or systematically using services rendered by the company.

In dealing with the issue of the trade tax jurisdiction in 2017, Supreme Court of the United States hearing a case of South Dakota v. Wayfair Inc. ${ }^{16}$ refused to apply the traditional requirement of physical presence and ruled that "a business may be present in a State in a meaningful way without" that presence "being physical in the traditional sense of the term". Thus, the court extended the judicial practice formed in Quill Corp. v. North Dakota ${ }^{17}$ and National Bellas Hess, Inc. v. Department of Revenue of Illinois ${ }^{18}$ and maintained a new approach in tax law.

\footnotetext{
${ }^{16}$ South Dakota v. Wayfair, Inc., 585 U.S. (2018).

${ }^{17}$ Quill Corp. v. North Dakota, 504 U.S. (1991).

${ }^{18}$ National Bellas Hess, Inc. v. Department of Revenue of Ill., 386 U.S. (1967).
} 
DOI: 10.14807/ijmp.v11i9.1429

A similar concept of permanent establishment of virtual services in the framework of existing double taxation agreements was introduced by OECD in 2018 (ORGANISATION FOR ECONOMIC CO-OPERATION AND DEVELOPMENT, 2018). Although welcomed by Saudi Arabia and India, the concept failed to get a wider international support. Such treatment of the permanent establishment could have been interpreted much wider going beyond the boundaries of the electronic environment to include consulting services, call centres, etc. Nation states saw a risk of legal disputes caused by the indefinite interpretation of permanent establishment.

Nearly at the same time, the European Commission proposed new rules for taxing businesses operating in the electronic environment (EUROPEAN COMMISSION 2020). The proposal was a necessary measure by the Commission until OECD finds a digital business taxing solution acceptable to the international community. As the progress in the field is slow, the European Commission extended the existing concepts of permanent establishment by acknowledging digital representation of businesses in foreign countries. Digital services to be included into the scope of business have to be rendered over the Internet or an electronic network and have to meet the following criteria:

- the service must be automated,

- human interference into the service provision must be limited to minimum,

- the service provision must be impossible without information technologies (EUROPEAN COMMISSION 2020).

Although the European Commission has extended boundaries of the permanent establishment, the initial changes comprise only part of business activities, i.e. the digital representation per fiscal year has to be significant, which means the company's revenue from electronic services in the jurisdiction has to be at least 7 mil euros or the company has to serve at least 100000 end users or have at least 3000 contracts on e-service provision in the target country (EUROPEAN COMMISSION 2020).

OECD proposals of 2019 also envisage estimation of business revenue limitations as a key criterion grounding application of the new rules of PE interpretation linking the company to the state's jurisdiction and granting the state the right to impose taxes on the company's revenue (ORGANISATION FOR ECONOMIC CO-OPERATION AND DEVELOPMENT, 2019). It means that only a limited number of companies are likely to fall within the scope of the new regulation. 
DOI: 10.14807/ijmp.v11i9.1429

The regulation does not extend on small and medium enterprises. Companies not meeting the aforementioned requirements will not be subject to income taxing. However, if the approach was adopted, each nation state would have to set business revenue limitations for the tax burden to appear in its jurisdiction (TURINA, 2019).

One of the means for companies to ascribe their customer to a certain jurisdiction is the Internet Protocol (IP) address. However, companies may use other means of the customer location as well. For instance, the number of devices connected to the digital interface through which the digital services are supplied may be used as a suitable and sufficient technique to assess the proportion of total revenues of the company (COMMISSION RECOMMENDATION, 2018).

However, little is said about measures to be applied by tax administering institutions to ensure efficient operation of the system. Without such instruments, we may end up having a system designed only for big business. It seems that nation states are just desperately seeking to regain lost income from big corporations ${ }^{19}$ making little or no efforts to develop a fair and efficient taxation system.

The minimal measures envisaged by the European Commission greatly remind the electronic services taxation scheme introduced at the beginning of the century where the implementation measures were absolutely inefficient in case of small and medium enterprises registered outside the EU. The system aimed at improvement of large business tax administration (undoubtedly important as well) leaving the question tax inevitability for small and medium business unresolved. Electronically provided services remained beyond the scope of tax monitoring. The partial system operation was based on the knowledge of big companies subject to registration in the system. There were no measures to identify non-registered businesses subject to such registration according to the nature of their business operations.

\section{CONCLUSIONS}

Failure by the international community to adopt a universal approach to taxing revenues raised from e-commerce predetermines isolated endeavours by individual states to develop new rules of international taxation. Meanwhile, international taxation may only be effective in presence of multilaterally agreed rules. The wider such rules are acknowledged, the more effective their implementation may be expected. Therefore, it is essential to curb further development of unilateral initiatives to preclude their evolution into long-term national

19 The attention paid to big corporations should only be an impetus to start a reform in taxation (MORENO; BRAUNER, 2019). 
DOI: 10.14807/ijmp.v11i9.1429

strategies. As OECD fails to find a widely acceptable solution, nation stated are desperately trying to regain their lost tax revenues ignoring the need to develop a modern internationally acknowledged taxation system. As a leading organization, OECD has to ensure that the newly developed taxation system is acceptable to the vast majority of nation states.

The newly developed system of taxing e-commerce companies must be grounded on the source principle. The principle of fairness is essential in the system to apply equally to big, small and medium enterprises. It must be developed as a system extending upon all ecommerce business and not applicable only to specific cases (big e-commerce companies in the present context).

The extended understanding of the permanent establishment has to be universally acknowledged and acceptable to the international community instead of being reflected only in individual court decisions. Attributing a permanent establishment to tangible assets, which has lasted for over a century, has be fully rejected in favour of an up-to-date fair and efficient PE concept suitable to modern cyberspace business. The key focus in PE creation must be on relations between the state and economic activities of the company.

\section{REFERENCES}

BASU, S. (2017) International Direct Taxation and E-Commerce: A Catalyst for Reform. NUJS Law Review, v. 10, n. 1, p. 19-48.

BRAUNER, Y. (2003) An International Tax Regime in Crystallization. Tax L. Rev., 56, p. 259-328.

COMMISSION RECOMMENDATION of 21.3.2018 relating to the corporate taxation of a significant digital presence. Brussels, 21.3.2018 C (2018) 1650 final. Available: $<$ https://ec.europa.eu/taxation_customs/sites/taxation/files/g_recommendation_significant_di gital_presence_21032018_en.pdf>. Access: 22 February 2020.

DA SILVA, MINELLE ENEAS; NASCIMENTO, LUIS FELIPE (2015) Emphasizing social issues toward sustainable supply chain: a Brazilian perspective. Independent Journal of Management \& Production, v. 6, n. 2, p. 478-494.

DANON, R. J.; SPINOSA, L.; TURINA, A. (2018) Tax Challenges Raised by the Digital Economy. Le droit social numérique, p. 169-191.

EUROPEAN COMMISSION (2017) A Fair and Efficient Tax System in the European Union for the Digital Single Market, COM(2017) 547 final. Access: 21 May 2020.

EUROPEAN COMMISSION (2020) Fair Taxation of the Digital Economy. Available: $<$ https://https://ec.europa.eu/taxation_customs/business/company-tax/fair-taxation-digitaleconomy_en>. Access: 22 February 2020. Access: 17 April 2020.

FAULHABER L. V. (2019) Taxing Tech: The Future of Digital Taxation. Virginia Tax Review 39.2, p. 145-196. Available: <https://ssrn.com/abstract=3460741>. Access: 18 April 2020.

GHOTBIFAR, F.; MARJANI, M.; RAMAZANI, A. (2017) Identifying and assessing the 
factors affecting skill gap in digital marketing in communication industry companies. Independent Journal of Management \& Production, v. 8, n. 1, p. 1-14. DOI: http://dx.doi.org/10.14807/ijmp.v8i1.507.

GUTMAN, M.G. (2001) Taxation of Income Derived from Electronic Commerce: Argentina. 55TH CONGRESS OF THE INTERNATIONAL FISCAL ASSOCIATION, v. LXXXVI, p. 215-241.

HENRIQUES, A.C.V.; MEIRELLES, F.S.; CORTEZ DA CUNHA, M.A. (2020) Big data analytics: achievements, challenges, and research trends. Independent Journal of $\begin{array}{llllllll}\text { Management } \quad \text { \& } & \text { Production, } & \text { v. } & 11, & \text { n. } & 4, & \text { p. } & 1201-1222 .\end{array}$ DOI: dx.doi.org/10.14807/ijmp.v11i4.1085

HMAYAKYAN, H. (2019) Taxation in the Cyber Age: The Future of Wayfair. Loyola of Los Angeles Entertainment Law Review, v. 39, n. 3, p. 285-321.

HONGLER, P.; PISTONE, P. (2015) Blueprints for a New PE Nexus to Tax Business Income in the Era of the Digital Economy. WU International Taxation Research Paper Series No. 2015 - 15, p. 17. DOI: 10.2139/ssrn.2586196.

MODEL TAX CONVENTION on Income and on Capital. OECD, 2017.

MORENO, A. B.; BRAUNER, Y. (2019) Taxing the Digital Economy Post BEPS - Seriously. Columbia Journal of Transnational Law, v. 58, n. 1, p. 121-188.

ORGANISATION FOR ECONOMIC CO-OPERATION AND DEVELOPMENT (2019) Public Consultation Document: Secretariat Proposal for a "Unified Approach" under Pillar One. Available: <https://www.oecd.org/tax/beps/public-consultation-documentsecretariat-proposalunified-approach-pillar-one.pdf> . Access: 22 February 2020.

ORGANISATION FOR ECONOMIC CO-OPERATION AND DEVELOPMENT (2020) Tax Challenges Arising from Digitalisation - Interim Report 2018: Inclusive Framework on BEPS, OECD/G20 Base Erosion and Profit Shifting Project, paras. 379, Available: $<$ https://www.oecd.org/fr/fiscalite/tax-challenges-arising-from-digitalisation-interim-report9789264293083-en.htm>. Access: 22 February 2020.

REIS, J.G.M.; NETO, P.L.O.C.; FUSCO, J.P.A.; MACHADO, S.T. (2014) Supply chain strategies in the context of an e-commerce chain (e-chain). Independent Journal of $\begin{array}{lllllll}\text { Management } \quad \text { \& } & \text { Production, } & \text { v.5, } & \text { n. } & 2, & \text { p. } & \text { 438-457. }\end{array}$ DOI: http://dx.doi.org/10.14807/ijmp.v5i2.148.

REUVEN, S. A. (2000) Globalization, Tax Competition, and the Fiscal Crisis of the Welfare State. Harv. L. Rev., v. 113, n. 7, p. 1573-1676.

SIMANJUNTAK, M. (2020) Consumer empowerment on online purchasing. Independent Journal of Management \& Production, v. 11, n. 1, p. 236-255. DOI: dx.doi.org/10.14807/ijmp.v11i1.964

SKAAR, A. A. (2000) Erosion of the Concept of Permanent Establishment: Electronic Commerce. Intertax, v. 28, n. 5, p. 188-194.

TAXATION AND ELECTRONIC COMMERCE, OECD 2001. Implementing the Ottawa Taxation Framework Conditions.

TURINA, A. (2019) The progressive policy shift in the debate on the international tax challenges of the digital economy: A "Pretext" for overhaul of the international tax regime? Computer Law \& Security Review, p. 1-17. 
VAN RAAD, K. (2001) International Coordination of Tax Treaty Interpretation and Application. Intertax, v. 29, n. 6-7, p. 212-218.

WAGNER CARDOSO, W.; JUNIOR, W.A.; BERTOSSE, J.F.; BASSI, E. \& PONCIANO, E.S. (2017) Digital manufacturing, industry 4.0, clould computing and thing internet: Brazilian contextualization and reality. Independent Journal of Management \&

Production, v. 8, n. 2, p. 459-473. DOI: dx.doi.org/10.14807/ijmp.v8i2.572. 